\title{
OPEN
}

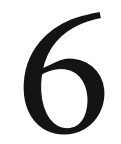

\section{The University Press and the Academic Book of the Future}

\section{Anthony Cond}

\begin{abstract}
Long perceived as a bastion of the academic book, the university press now finds itself operating under a range of business models, in an increasing number of possible locations on campus, and with the measurement of 'success' markedly different across host institutions. Yet this study of the underpinning rationale for a growth in university press publishing in the UK, and of the award of major grants to several US presses, highlights that the university press remains a barometer for proposed structural changes to knowledge dissemination and debates around the future of the book in the academy.
\end{abstract}

Keywords: digital publishing; humanities; monograph; Open Access; university press

Lyons, Rebecca E. and Samantha J. Rayner (eds). The Academic Book of the Future. Basingstoke: Palgrave Macmillan, 2016. DOI: 10.1057/9781137595775.0012. 
Much like the humanities field it so often serves, the university press has endured many decades of self-diagnosed crisis and introspective selfreflection. A report from the University of Chicago Press's Director in 1927 noted editorial and authorial concerns over such familiar issues as 'excessive specialization', and an inability to publish important scholarly work with small audiences. ${ }^{1}$ This long-standing hand-wringing emerged, not least because of debates around the relative value - in library budget terms, among others - of humanities research, the outputs of which have frequently been that cornerstone of the university press publishing programme: the monograph. Thus the university press enjoys a peculiar position: a publishing island atop a sea of academia, its insecurities a mirror to the budgetary, utility and reputational concerns of the subjects and institution it serves.

One in six university presses now reports to a library. ${ }^{2}$ Presses otherwise report to senior university managers or university or quasiuniversity committees; their editorial boards are drawn from faculty, yet more faculty are engaged as series editors, authors and reviewers, and more still in the inevitable exchange of ideas that happens when an academic department and a scholarly publisher active in its discipline are in close proximity. The university press is, thus, a touch point - above and beyond the author/purchaser/reader relationship with commercial publishers - between the academy's hopes and fears and the realities of the scholarly communication system, all the more so in recent years as savvy press directors have become more engaged in wider institutional politics in order to navigate institutional reorganisation. In thinking about the medium-term future of the academic book, changes in the university press landscape provide a tantalising glimpse of how a much written about soup of Open Access, digital scholarship, funding policies, authorial conservatism, challenging library budgets, publishing consolidation, internationalisation and new business models may be consumed.

In particular, a reading of the most recent round of grants from the Andrew W. Mellon Foundation gives an idea of how a future of the academic book is perceived by that great engine of scholarly book production, the membership of the Association of American University Presses (AAUP), who, according to the Association's website, collectively publish almost 15 , 0oo books each year. ${ }^{3}$ Whilst the 2015 annual conference of the AAUP provocatively included the panel 'When Publishers Aren't Getting It Done', the Mellon grants 
have provided much-needed capital for university presses to plan for the future. As Donald J Waters, Senior Programme Officer at the Foundation, has put it: 'University presses are seeking to retool their operations to take advantage of digital media and digital workflows to bring new works of scholarship to the broadest possible audiences at the lowest possible cost.'4

In May 2014, the Mellon Foundation sent university press directors a request for proposals for long-form digital publishing for the humanities. Noting the growth of digital scholarship, the Foundation recognised an 'urgent and compelling' need for university presses to publish and make digital work available to readers. It also recognised that it was challenging to find the resources that are needed to do so. The Foundation therefore asked university presses to submit collaborative bids to test new longform digital publishing business models, or tackle its component parts, such as (1) editing; (2) clearing rights to images and multimedia content; (3) the interaction of the publication on the Web with primary sources and other related materials; (4) production; (5) pre- and post-publication peer review; (6) marketing; (7) distribution; and (8) maintenance and preservation of digital content. ${ }^{5}$

Projects that received funding from Mellon in response to this call, and in related funding immediately before and after it as 'part of Mellon's overall initiative in academic publishing', can be grouped into three broad categories: digital book platforms, Open Access tools and distribution channels, and platforms for enriching the user experience of books both before and after publication: ${ }^{6}$

- The University of North Carolina Press received \$998,00o to develop a collaborative services platform for university presses, which will be used to facilitate cost efficiencies on a broad range of digital publishing activities, including copy-editing, composition, production, operations, and marketing services as part of the development of digital monographs.

- New York University Press, publisher of Kathleen Fitzpatrick's seminal Planned Obsolescence: Publishing, Technology, and the Future of the Academy, a book that has clearly influenced much of the thinking around the grant programme, received $\$ 786$, ooo to develop an infrastructure for enhanced networked monographs to support the editing, production, dissemination, and discovery of long-form digital publications in the humanities. 
- University of Minnesota Press will work with CUNY's GC Digital Scholarship Lab to develop 'Manifold Scholarship', a project that will 'develop, alongside the print edition of a book, an alternate form of publication that is networked and iterative, on an interactive open-source platform.' Ebook editions will allow authors to link to or incorporate rich media content, primary sources and datasets. Reader feedback - separate from peer review - will be incorporated via social media channels.

- The University of Michigan Press and partners at Indiana, Minnesota, Northwestern and Penn State, received grant money to build a hosted platform for managing monographic source materials and born digital publications. In practice, this means that an existing repository infrastructure will be 'extended to accommodate the interactive presentation of digital materials linked to humanities monographs through stable URLs and Digital Object Identifiers (DOIs) printed in paper versions and additional clickable links in electronic formats. ${ }^{8}$

- The University of California Press and the California Digital Library will develop a web-based open-source content management system to support the publication of Open Access monographs in the humanities and social sciences. When complete, the system will be made available to other university presses and library publishers. ${ }^{9}$

- Johns Hopkins University Press received support from Mellon for the further development of that most successful example of University Press collaboration, Project Muse. MUSE Open will see Open Access monographs distributed globally and 'made visible and usable through discoverability and accessibility tools normally reserved for paid content' under the banner of one of the most trusted intermediaries.

- Stanford University Press has channelled its grant into establishing a robust peer review process for interactive scholarly research projects, including a system and framework for publishing and distributing digital-born scholarship.

- Yale University Press will establish a new electronic portal on which customisable art and architectural history content, drawn from Yale's backlist, will be made available to consumers and institutions.

- Although not strictly university press awards, the programme also gave $\$ 1.3$ million to Brown University ${ }^{10}$ to support capacities 
at universities and presses for the development, publication, and preservation of born-digital interactive scholarly works, including a focus on the legitimisation of digital scholarship to ensure that digital and traditional scholarship are given equal credit in tenure and promotion; and \$1million to West Virginia University for the development of Vega, ${ }^{11}$ an online open sources academic publishing system that will support the peer review, copy-editing, and publication of multimedia-rich scholarship.

Is this, then, the direction of travel for the academic book of the future? In some cases certainly: it will be digital, it will be iterative, the cost of making it available in Open Access form (if so desired) will reduce through a shared infrastructure, it will be rich in supporting data, and the esteem of the university press brand and the rigour of university press peer review will be brought to bear on all of this. But it has been a mistake of a great many publishing commentators to pronounce on the future of the academic book when there is in fact no one future for it. Indeed, perhaps the sole common future of all kinds of academic book will be the process of credentialisation as being 'academic'.

According to a 2014 survey of 2231 academics undertaken by JISC, ${ }^{12} 83$ per cent of humanities scholars use electronic scholarly books but 87 per cent used a print copy for the last text they read. While percentages are no doubt in flux they point to an audience regularly imbibing scholarly research in more than one format, rather than an exclusively digital one. It is unlikely that the audience for print will disappear entirely. Intriguingly, of the 98 per cent of respondents who felt that reading the monograph was important or very important for career purposes only 10 per cent of respondents felt that it was difficult or very difficult to access monographs, which suggests that any significant growth in readership for the academic book in whatever form it takes will come from outside its conventional audience, regardless of new distribution strategies.

The practice of iterative publication, of utilising networked technologies and online communities, offers the potential for a deeper and more varied engagement from readers at different stages of the publication process. Research undertaken by Palgrave in $2014^{13}$ showed that over two-thirds of the authors they surveyed thought publishers should be experimenting with alternative peer review methods: 'Responses indicated that rather than this interest being driven by dissatisfaction with existing peer review methods, it was inspired by curiosity in what new 
approaches might offer.' However, as Kathleen Fitzpatrick notes, 'even the most ingenious new structures for publishing a text online will not automatically get any randomly selected group talking. Technologies like these can, however, facilitate discussions among those who are both motivated and prepared to have them. ${ }^{14}$ The process will require careful curation to solicit engagement, requiring either a financial investment by publishers or one of time by authors, who, like their potential readers/ reviewers already face the demands of teaching, research, 'knowledge exchange', conferences, writing and reviews of traditional scholarship, and so on.

The cost of long-form Open Access publishing will inevitably decrease through the welcome establishment of a robust, shared infrastructure, but it is still unlikely that processing charges associated with gold Open Access will drop to a level that is readily obtainable for the majority of academics, libraries and university departments without external funding. Much rides on the scalability of high-profile Open Access book initiatives such as Knowledge Unlatched, which piloted with a predominantly university press roster of publishers, and the nascent, Mellonfunded Open Library of the Humanities, which has mooted a books programme with a small group of university presses. The most rigorous assessment of Open Access business models to date, the Monographs and Open Access report led by Professor Geoffrey Crossick concluded: 'There is no single dominant emerging business model for supporting OpenAccess publishing of monographs; a range of approaches will coexist for some time and it is unlikely that any single model will emerge as dominant. ${ }^{35}$

Open Access monographs, then, will be an addition to, rather than substitution of, existing practice, and will be published under a range of models, but another thread of Open Access book publishing is also beginning to gain traction on both sides of the Atlantic: the textbook. In an age when the 'student experience' is king, with an increasingly diverse and international student body, and with teaching income the largest source of revenue for many institutions, the opportunity to develop bespoke Open Access e-textbooks, as is happening at the University of Liverpool - in a partnership between press and library - provides a real institutional benefit. Whilst this turn inwards in a future that is global may seem counter-intuitive, it is worth noting that the first fruits of the project will replace a textbook from a commercial publisher that costs $£ 56$ and has been a compulsory purchase for 900 students on campus 
each year. Indeed, JISC's wider project, The Institution as E-Textbook Publisher project seeks to ascertain whether the institution as e-textbook creator can 'help students by providing a more affordable higher education, and promote a better, more sustainable information environment for libraries, students and faculty.' ${ }^{16}$

UCL Press, another participant in the JISC project, is one of a raft of new UK university presses that have emerged in the last few years ${ }^{17}$ unencumbered with legacy and with a forward-looking strategy. University College London, one of the largest and wealthiest UK higher education institutions, has been a public supporter of Open Access. Its new press is funded from the university's research budget, underpinned by a belief, following Kathleen Fitzpatrick, that universities should reassert their role in the scholarly dissemination workflow and outputs. Dissemination is UCL Press's goal and its measures of success are based on that idea, with the benefits of visibility for institutional research, wider use by policy makers and the hope of attracting academics and students to the institution as additional perceived benefits. ${ }^{18}$

In a similar vein, institutions from Goldsmiths to Cardiff, Westminster to Amherst College in the US have announced new university presses embracing Open Access, digital technology and a mixture of 'standard' and 'non-standard' forms of publication. Just as some universities were prompted by developments in digital printing to experiment with university press publishing, so Open Access and digital publishing has created a willingness in some institutions to invest not just in ownership of conventional publications but to create new kinds of publication that sit outside conventional silos.

It is worth reiterating that these new ventures, and the Mellon grants, are not the strategies and aspirations of publishers in isolation. By the nature of the university press, at some level there will have been input or approval or both from scholars, and often senior university managers and librarians. They show us that it is in the mix of publishing practicality and scholarly satisfaction or dissatisfaction with the current system that the future of the book lies. Where once hardback and paperback sufficed, a variety of formats developed in a variety of ways must be offered to continue the university press mission of supporting the dissemination of scholarship, for, as Joseph Esposito has observed, 'It's not what the presses preserve that is important but the work that they have yet to do. Universities invent the future, presses communicate those inventions to the world.'19 
The signs so far are of a slow evolutionary branching rather than a radical revolution of the academic book. Its future is, above all, one of choice for author and reader alike. While the Mellon Foundation has hinted at further interventions, including possible pump-priming for an institutional sponsorship model, the academic book sits within a complex global web with many stakeholders and overnight change is unlikely. In preparing for a diverse future of the book, university presses would do well to heed the words of Rick Anderson: 'Libraries and patrons don't care if a publisher's strategy is innovative. Don't bet your future on innovation. Focus on increasing relevance.20

\section{Notes}

1 Bean cited in A. Abbot (27 June 2008) 'Publication and the Future of Knowledge', Presentation to the Association of American University Presses, http://home.uchicago.edu/ aabbott/Papers/aaup.pdf, accessed 20 August 2015.

2 J. Howard (24 June 2013) 'For University Presses, a Time of Fixing Bridges, and Building New Ones', The Chronicle of Higher Education, http://chronicle. com/article/For-University-Presses-a-Time/139983/, accessed 20 August 2015.

3 See 'About the AAUP', AAUP, http://www.aaupnet.org/index.php, accessed 20 August 2015.

4 G. Mahalek (8 January 2015) 'The University of North Carolina Press Receives Major Grant from Mellon Foundation', Publisher's Weekly, http://www. publishersweekly.com/binary-data/NEWS_BRIEFS/attachment/ooo/ooo/6-1. pdf, accessed 20 August 2015.

5 Cited in C. Straumsheim (25 February 2015) 'Piecing Together Publishing', Inside Higher Ed, https://www.insidehighered.com/news/2015/02/25/ researchers-university-press-directors-emboldened-mellon-foundationinterest, accessed 20 August 2015.

6 For more detail on the main awards use the links on the AAUP website: http:// www.aaupnet.org/aaup-members/news-from-the-membership/collaborativepublishing-initiatives, accessed 20 August 2015.

7 University of Minnesota Press (20 April 2015) 'The University of Minnesota Press partners with CUNY's GC Digital Scholarship Lab to launch Manifold Scholarship - a platform for iterative, networked monographs - with grant from the Andrew W. Mellon Foundation', University of Minnesota Press website, https://www.upress.umn.edu/press/press-releases/manifoldscholarship, accessed 20 August 2015. 
8 Michigan Publishing (April 2015) 'Building a Hosted Platform for Managing Monographic Source Materials and Born Digital Publications through Library/Press Collaboration', Michigan Publishing website, http://www. publishing.umich.edu/files/2015/o4/Hydra_Fedora_Mellon_Proposal_ Summary.pdf, accessed 20 August 2015.

9 R. Poynder (8 March 2015) 'The OA Interviews: Alison Mudditt, Director, University of California Press', Open and Shut? (blog), http://poynder. blogspot.com/2015/o3/the-oa-interviews-alison-mudditt.html, accessed 20 August 2015.

10 C. Coelho (12 January 2015) 'Mellon Grant to Fund Digital Scholarship Initiative', Brown University website, https://news.brown.edu/ articles/2015/01/digital, accessed 20 August 2015.

11 C. Ball (7 October 2014) 'Proposal to The Andrew W. Mellon Foundation', Dr. Cheryl E. Ball, An Academic Portfolio, http://ceball.com/wp-content/ uploads/2015/o1/PORTFOLIO-COPY-WEB.pdf, accessed 20 August 2015.

12 OAPEN-UK (2012) 'Survey of Use of Monographs by Academics - as Authors and Readers', OAPEN-UK, http://oapen-uk.jiscebooks.org/ files/2012/O2/OAPEN-UK-researcher-survey-final.pdf, accessed 20 August 2015.

13 H. Newton (28 February 2014) 'Experiment in Open Peer Review for Books Suggests Increased Fairness and Transparency in Feedback Process', LSE Impact Blog, http://blogs.lse.ac.uk/impactofsocialsciences/2014/o2/28/ palgrave-macmillan-open-peer-review-for-book-proposals/, accessed 20 August 2015.

14 K. Fitzpatrick (2011) Planned Obsolescence: Publishing, Technology, and the Future of the Academy (New York: New York University Press).

15 G. Crossick (2014) Monographs and Open Access: A Report to HEFCE, http://www.hefce.ac.uk/media/hefce/content/pubs/indirreports/2015/ Monographs,and,open,access/2014_monographs.pdf, accessed 20 August 2015.

16 Jisc, 'Institution as e-textbook Publisher', Jisc Collections website, https:// www.jisc-collections.ac.uk/Institution-as-E-textbook-Publisher/, accessed 20 August 2015.

17 A. Cond (18 August 2015) 'The University Press Is Back in Vogue', The Bookseller (blog), http://www.thebookseller.com/blogs/anthony-cond-30936o, accessed 20 August 2015.

18 P. Ayris, E. McLaren, M. Moyle, C. Sharp and L. Speicher (2014) 'Open Access in UCL: A New Paradigm for London's Global University in Research Support', Australian Academic \& Research Libraries 45(4): 282-95.

19 J. Esposito (7 March 2011) 'The New Economics of the University Press - A Report from the AAUP', Scholarly Kitchen (blog), http://scholarlykitchen. sspnet.org/2011/03/o7/the-new-economics-of-the-university-press-a-reportfrom-the-aaup/, accessed 20 August 2015. 
20 AAUP (2014) 'Library-Press Connections at the Charleston Conference', AAUP website, http://www.aaupnet.org/news-a-publications/aauppublications/the-exchange/current-issue/1265-charleston-2014, accessed 20 August 2015.

(c) (i) Except where otherwise noted, this work is licensed under a a copy of this license, visit https://creativecommons.org/version4 